\title{
BIOACTIVE COMPOUNDS AND TOTAL ANTIOXIDANT CAPACITY OF CASHEW APPLES (Anacardium occidentale L.) DURING THE RIPENING OF EARLY DWARF CASHEW CLONES
}

\author{
Compostos bioativos e atividade antioxidante total de pedúnculos de caju \\ (Anacardium occidentale L.) durante o amadurecimento de clones de cajueiro anão-precoce
}

\author{
Mônica Maria de Almeida Lopes', Maria Raquel Alcântara de Miranda², \\ Carlos Farley Herbster Moura ${ }^{3}$, Joaquim Enéas Filho
}

\begin{abstract}
Lately, tropical fruit consumption has increased due to a higher knowledge of its nutritional and therapeutic value. The aim of this work was to evaluate the antioxidant potential of cashew apples from different early dwarf clones during their ripening. The clones analyzed included: CCP 76, CCP 09, BRS 189 and BRS 265 in seven ripening stages. They were analyzed for vitamin C, total carotenoid, total anthocyanin, yellow flavonoids and polyphenol content and total antioxidant capacity. Clone BRS 265 ripe cashew

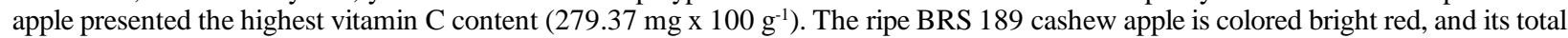

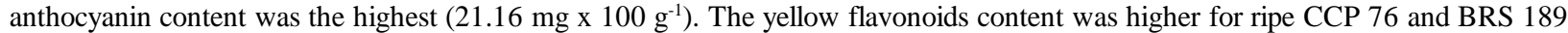
cashew apples with 56.32 and $50.75 \mathrm{mg} \mathrm{x} 100 \mathrm{~g}^{-1}$, respectively. The highest levels of extrable polyphenols and antioxidant capacity were observed in CCP 09 in the first five ripening stages. The antioxidant activity of cashew apples (Anacardium occidentale L.) is mainly attributed to polyphenol content $(\mathrm{r}=0.90 ; p<0.01)$, and, therefore, they may be considered relevant sources of antioxidant compounds, which are necessary for human health. Cashew apples are consumed fresh which confers direct benefits for human health and present high potential for the development of new products with functional properties.
\end{abstract}

Index terms: Polyphenols, ABTS, vitamin C, carotenoids, food analysis.

\section{RESUMO}

Ultimamente, o consumo de frutas tropicais tem aumentado em razão de um maior conhecimento de seu valor nutricional e terapêutico. Neste trabalho, objetivou-se avaliar o potencial antioxidante de pedúnculos de cajus de diferentes clones de cajueiro anão precoce, durante o seu amadurecimento. Os clones analisados foram: CCP 76, CCP 09, BRS 189 e BRS 265, em sete estádios de amadurecimento. Foram analisados para a vitamina $\mathrm{C}$ total, antocianinas, carotenóides totais, flavonóides amarelos, teor de polifenóis e capacidade antioxidante total. O clone BRS 265 maduro obteve o maior teor de vitamina $\mathrm{C}\left(279,37 \mathrm{mg} 100 \mathrm{~g}^{-1}\right)$. O pedúnculo

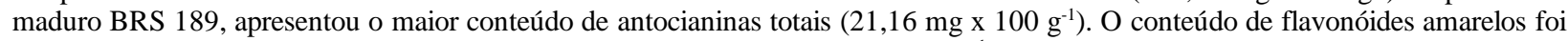
maior para os clones CCP 76 e BRS 189 maduros, com 56,32 e 50,75 mg x $100 \mathrm{~g}^{-1}$, respectivamente. Os maiores teores de polifenóis extraíveis e atividade antioxidante total foram encontrados no clone CCP 09 nos primeiros cinco estádios de maturação. A atividade antioxidante de pedúnclos de caju (Anacardium occidentale L.) é atribuída principalmente ao teor de polifenóis $(r=0,90, p<0,01)$, e, portanto, eles podem ser considerados fontes relevantes de compostos antioxidantes, que são necessários para a saúde humana. Os pedúnculos quando consumidos frescos, conferem benefícios diretos para a saúde humana e, também, apresentam um grande potencial para o desenvolvimento de novos produtos com propriedades funcionais.

Termos para indexação: Polifenóis, ABTS, vitamina C, carotenóides, análise de alimentos.

(Received in march 28, 2012 and approved in april 28, 2012)

\section{INTRODUCTION}

Brazil possesses many native and well-adapted tropical fruit species that have great marketing potential in natura or in the processing industry (ALVES et al., 2008). Lately, tropical fruit consumption has increased due to a greater knowledge of its nutritional and therapeutic value (ESPIN et al., 2000).

The cashew tree is native to Brazil and is of socioeconomic importance to northeastern Brazil and other countries, such as Nigeria, Tanzania and Mozambique (PETINARI; TARSITANO, 2002). Both the nut (fruit) and the cashew apples or pseudofruit are commercialized from the cashew tree, although the nut has a much broades market. The cashew apples is juicy with a pleasant flavor and a very fragile skin. this characteristic makes it sensitive to mechanical damage, requiring care during transportation. Thus, it is preferably marketed as processed frozen pulp, juice or nectar.

\footnotetext{
${ }^{1}$ Universidade Federal do Ceará/UFC - Departamento de Bioquímica e Biologia Molecular - 60.455-970 - Fortaleza - CE - Brasil monicalopes5@hotmail.com

2Universidade Federal do Ceará/UFC - Departamento de Bioquímica de Biologia Molecular - Fortaleza - CE - Brasil

${ }^{3}$ Empresa Brasileira de Pesquisa Agropecuária/Embrapa - Agroindústria Tropical - Fortaleza - CE - Brasil
} 
Ripe cashew apples are a good source of healthpromoting nutrients, such as ascorbic acid, and according to Contreras-Calderón et al. (2011), cashew apples possess a

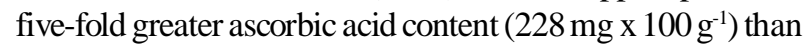
oranges (SILVA et al., 2007). Besides vitamin C, ripe cashew apples contain several other compounds with antioxidant potential, including carotenoids $\left(0.40 \mathrm{mg} \mathrm{x} 100 \mathrm{~g}^{-1}\right)$, yellow

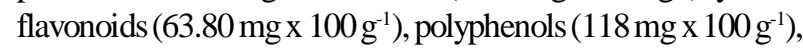
phenolic acids and oligomeric tannin $\left(29 \mathrm{mg} \times 100^{-1}\right)$ (RUFINO et al., 2010; MICHODJEHOUN-MESTRE et al., 2009).

Natural antioxidants play an important role as an endogenous plant defense system. Moreover, their consumption confers protection against some degenerative human diseases, as the generation of oxidant radicals is a normal phenomenon in biological systems, such as animals and plants (SUJA et al., 2004; ESPIN et al., 2000).

Evidence suggests that the high content of fiber and antioxidants (e.g., ascorbic acid and polyphenols), of diets rich in fruits and vegetables may decrease the risk of chronic diseases (WORLD HEALTH ORGANIZATION - WHO, 2003).This beneficial effect is due to the action of antioxidant compounds, which are capable of neutralizing free radicals and reduce oxidative damage in the body (CLIFFORD, 1995). For this reason, the interest in the evaluation of antioxidant activity of fruits and vegetables has substantially increased and numerous studies have been performed (THILI et al., 2011; MEZADRI et al., 2008; ILAHY et al., 2011; PARK et al., 2011).

In this sense, antioxidant activity of cashew apples (Anacardium occidentale L.) is a topic interesting, because tropical fruit consumption is increasing on the domestic and international markets due to growing recognition of its nutritional and therapeutic value. Brazil boasts a large number of fruit species interest to the agroindustry and a possible future source of income for the local population (ALVES et al., 2008).

Identification and quantification of bioactive compounds and antioxidant properties of many fruits and vegetables are well defined, however, studies on the characterization and quantification of the antioxidant properties during ripening of early dwarf cashew clones are limited. In this study we investigated changes in major compounds antioxidants and antioxidant activity of four cashew apples cultivars harvested at seven different stages of ripening. The activity antioxidant and their correlation to different antioxidant compounds were also examined.

\section{MATERIAL AND METHODS}

\section{Chemicals and reagents}

The following reagents were used: 2,6dichloroindophenol (DFI), 2,2'-azino-bis (3ethylbenzthiazoline-6-sulphonic acid) (ABTS), 6-hydroxy2,5,7,8-tetramethyl chroman-2-carboxylic acid (trolox), folinciocalteu reagent and galic acid, all of which are from SigmaAldrich Chemical Co. (St. Louis, MO, USA). Potassium persulfate was acquired from Acrós Organics. All other reagents of analytical grade (sodium carbonate, sodium sulfate anhydrous, acetone, hexane, isopropyl alcohol, and methanol) were supplied by Vetec Quimica Fina (Rio de Janeiro, RJ, Brazil) and Labsynth (Diadema, SP, Brazil).

\section{Cashew apples harvest and sampling}

The cashew apples (Anacardium occidentale L.) evaluated were manually harvested at the Experimental Station of Embrapa Tropical Agroindustry in Pacajus-CE, Brazil (lat. $4^{\circ} 11^{\prime} 26,62^{\prime \prime} \mathrm{S}$, lon. 38 $29^{\prime} 50,78^{\prime \prime} \mathrm{W}$ ), in the early hours of the day, immediately placed in plastic boxes only one layer of cashew apples protected from mechanical injury. The early dwarf cashew clones analyzed included: CCP (Clone Cashew Tree Pacajus) 76, CCP (Clone Cashew Tree Pacajus) 09, BRS (Clone Brazil) 189 and BRS (Clone Brazil) 265 in seven ripening stages scored according to the skin color of the cashew apples and nuts(ALVES et al., 2008) (Table 1 and figure 1 ).

Table 1 - Subjective scale for ripening of orange (CCP76 and CCP 09) and red (BRS 265 and BRS 189) cashew apples from dwarf cashew clones.

\begin{tabular}{ccc}
\hline Maturity Stages & Orange Peduncle & Red Peduncle \\
\hline 1 & Green with green nut & Green with green nut \\
2 & Green with ripe dry nut & Green with ripe dry nut \\
3 & Light green & Light green \\
4 & Turning yellow & Turning orange \\
5 & Yellow turning orange & Orange turning red \\
6 & Light orange & Light red \\
7 & Dark orange & Dark Red \\
\hline
\end{tabular}

Ciênc. agrotec., Lavras, v. 36, n. 3, p. 325-332, maio/jun., 2012 


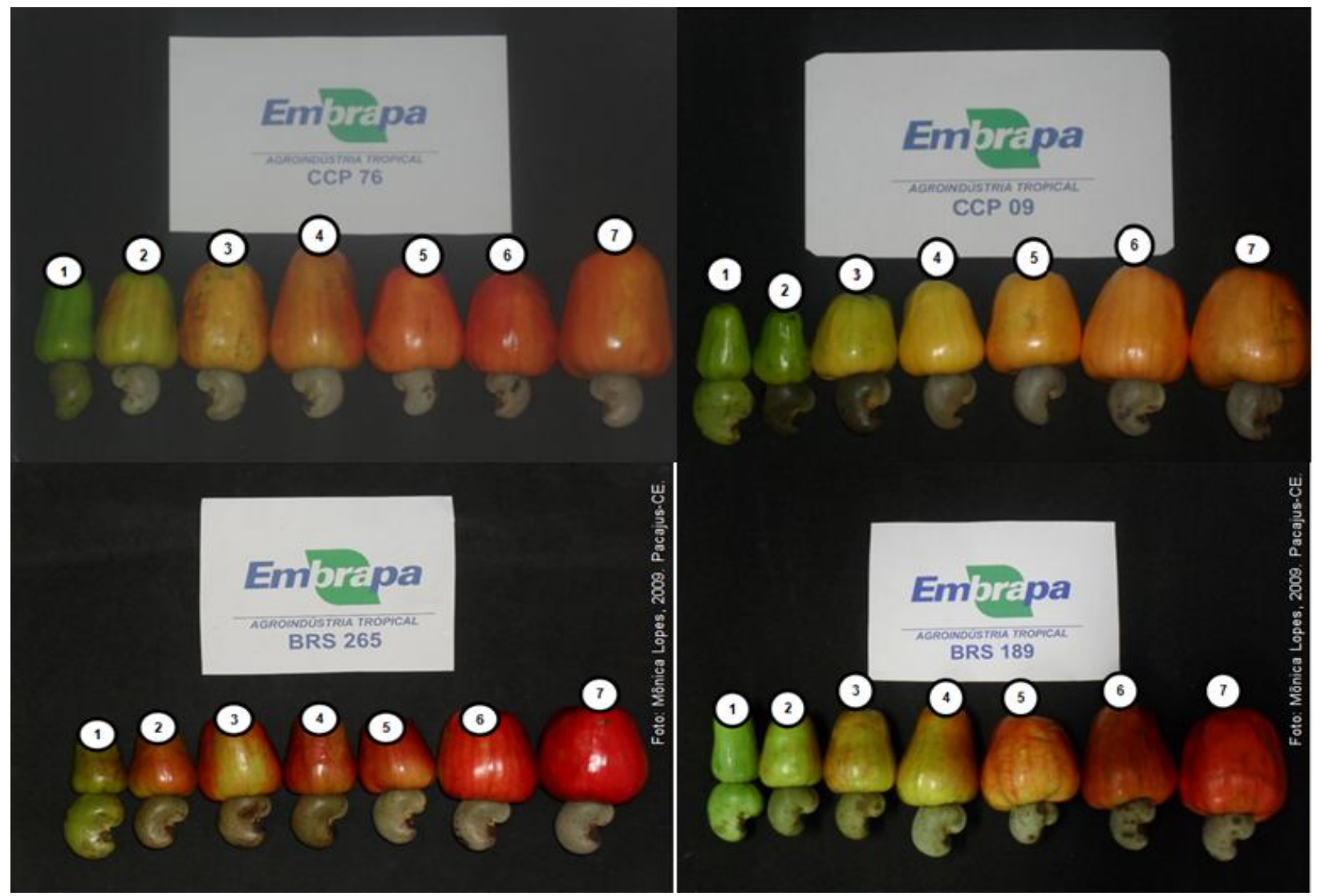

Figure 1 - Cashew apples of four early dwarf cashew clones harvested at the Experimental Station of Embrapa Tropical Agroindustry in Pacajus-CE. From left to right, stages of ripening 1 to 7.

After harvesting, the cashew apples were transported to Embrapa's Posthartvest Physiology and Technology Laboratory in Fortaleza - CE and processed in a domestic blender (Walita, Brazil) to obtain a pulp, which was then refrigerated at $-18^{\circ} \mathrm{C}$ until analysis was performed. A random design was used for the experiment, with seven treatments (ripening stages) and fifteen cashew apples divided into three replicates of five cashew apples for each stage analysed.

\section{Analytical determinations}

The total phenolic content was measured by a colorimetric assay using Folin Ciocalteu reagent (Sigma) as described by Obanda and Owuor (1997). Before the colorimetric assay, the samples were subjected to a procedure of extraction in $50 \%$ methanol and $70 \%$ acetone as described by Larrauri et al. (1997). For the colorimetric assay, $1 \mathrm{~mL}$ of Folin Ciocalteu (1:3) reagent, $2 \mathrm{mLNa} 2 \mathrm{CO} 3$ at $20 \%$ and $2.85 \mathrm{~mL}$ of distilled water were added to $150 \mu \mathrm{L}$ of extract. After incubation in the dark for $30 \mathrm{~min}$, absorbance was measured at $700 \mathrm{~nm}$. Gallic acid (Acrós Organics) was used as the standard, and results were expressed as gallic acid equivalents (GAE) $\mathrm{mg} \mathrm{x} 100 \mathrm{~g}^{-1} \mathrm{fw}$ (fresh weight).

Anthocyanins and yellow flavonoids were extracted and determined as described by Francis (1982). One gram of pulp was extracted with a $95 \%$ ethanol/1.5 N HCl solution (85:15), vortexed for 2 minutes and then brought to $50 \mathrm{~mL}$ with the extracting solution. Protected from the light, the mixture was refrigerated at $4^{\circ} \mathrm{C}$ for 12 hours and then filtered through Whatman N.1 paper; the filtrate was then gathered. The absorbance of the filtrate was measured at $535 \mathrm{~nm}$ for the total anthocyanin content using an absorption coefficient of 98.2 and at $374 \mathrm{~nm}$ for the total yellow flavonoid content using an absorption coefficient of 76.6, both results were expressed as mg. $100 \mathrm{~g}^{-1} \mathrm{FW}$.

The total vitamin $\mathrm{C}$ content was determined by performing a titration with Tillman solution $(0.02 \% 2.6$ dichloro-indophenol, DFI from Sigma) as described by

Ciênc. agrotec., Lavras, v. 36, n. 3, p. 325-332, maio/jun., 2012 
Strohecker and Henning (1967). One gram of pulp was diluted to $100 \mathrm{~mL}$ with $0.5 \%$ oxalic acid and then homogenized. Then, $5 \mathrm{~mL}$ of this solution was added to distilled water at the level of $50 \mathrm{~mL}$ and titrated. The results were expressed as mg x $100 \mathrm{~g}^{-1} \mathrm{fw}$.

Total carotenoids were extracted and determined as described by Higby (1962). Ten grams of pulp were homogenized in $30 \mathrm{~mL}$ of isopropyl alcohol and $10 \mathrm{~mL}$ of hexane. The content was transferred to a separation funnel of $125 \mathrm{~mL}$ completed with distilled water, and it allowed to rest for three $30 \mathrm{~min}$ periods followed by three subsequent filtrations. Filtration was performed in cotton previously sprayed with anhydrous sodium sulphate; $5 \mathrm{~mL}$ of acetone was added and then, the volume of $50 \mathrm{~mL}$ was completed with hexane. Absorbance was measured at $450 \mathrm{~nm}$, and the results were expressed as mg of total carotenoids $\mathrm{x} 100 \mathrm{~g}^{-1} \mathrm{fw}$.

The total antioxidant activity (TAA) was determined using the ABTS method as described by Re et al. (1999). This method measures the ability of lipophilic and hydrophilic antioxidants to quench a 2,2'-azino-bis 3ethylbenzthiazoline-6-sulphonic acid (ABTS*+, Sigma) radical cation. The radical solution was formed using 7 $\mathrm{mM} \mathrm{ABTS} *+$ and $140 \mathrm{mM}$ potassium persulfate and incubated for $16 \mathrm{~h}$ protected from light. Absorbance at 734 $\mathrm{nm} \mathrm{nm}$ was measured (results close to 0.700 ) to check $\mathrm{ABTS}^{*}+$ formation. Once the radical was formed, the reaction was started by adding $30 \mu \mathrm{L}$ of extract to $3 \mathrm{~mL}$ of radical solution. Absorbance was measured at $734 \mathrm{~nm}$ after $6 \mathrm{~min}$, and the decrease in absorption was used to calculate the total antioxidant activity (TAA). A calibration curve was prepared and different Trolox (Sigma) concentrations (standard trolox solutions ranging from 100 to $2000 \mu \mathrm{M}$ ) were also evaluated against the radical. Antioxidant activity was expressed as Trolox equivalent antioxidant capacity (TEAC), $\mu$ mol Trolox. $\mathrm{g}^{-1} \mathrm{fw}$.

\section{Statistical analysis}

Statistical analyses consisted of subjecting data to analysis of variance (ANOVA), and significant differences between clones were determined using a Scott-Knott's test at a 5\% significance level. To determine how the bioactive compounds contributed to the antioxidant capacity. Pearson's correlation coefficient was calculated using Student's t-test for all variables at $1 \%$ and $5 \%$ significance levels.

\section{RESULTS AND DISCUSSION}

After the complete ripening of cashew nuts at stage 1 , cashew apples from all four clones evaluated continued to grow and develop until stage 7 . The bioactive compounds changed significantly throughout the ripening of the cashew apples, as shown in table 2.

The total vitamin $\mathrm{C}$ content increased gradually, and the highest values for ripe cashew apples were found at stage 7. Clone BRS 265 ripe cashew apples had the greatest vitamin C content (279.37 mg x100 g-1 $)$. The rise in ascorbic acid levels during the last phase of cashew apples ripening may be attributed to a decline in the activity of ascorbate oxidase, the enzyme responsible for its degradation, or to a decline in levels of $\mathrm{Cu}^{++}$, which is a cofactor for ascorbate oxidase activity (CHEMPAKAM, 1983).

The pigments found during the ripening of the different clones reflect the changes in cashew apples color. Carotenoid pigments are not only important vitamin A precursors, but also display a considerable level of antioxidant activity. The total carotenoid content increased during ripening without any significant difference between clones. The total anthocyanins also increased with ripening; however, the red colored clones BRS 189 and 265 reached significantly higher values. The ripe BRS 189 cashew apples is colored bright red, and its total anthocyanin content was the highest $(21.16 \mathrm{mg} \mathrm{x}$ $\left.100 \mathrm{~g}^{-1}\right)$, this finding is not surprising because these phenolics are mainly responsible for the red, blue, and purple coloring of fruits. The yellow flavonoids content was greatest for ripe CCP 76 and BRS 189 cashew apples with 56.32 and $50.75 \mathrm{mg} \mathrm{x} 100 \mathrm{~g} \mathrm{~g}^{-1}$, respectively. These data agree with those reported by Filgueiras et al. (1999), who found that the color changes during maturation of cashew apples are caused by chlorophyll loss as well as the synthesis of other pigments. Total polyphenol content and antioxidant capacity of cashew apples from different clones are summarized in table 2.

The main dietary sources of phenolic compounds are fruits and beverages (SAURA-CALIXTO; GONII, 2006). However, the polyphenols decreased significantly throughout ripening of cashew apples. The lowest values were reached at ripening, particularly for clone BRS 189, which contained $54.8 \mathrm{mg} \mathrm{x} 100 \mathrm{~g}^{-1}$. Until stage 5, clone CCP 09 had significantly higher values of polyphenols. Other published works show great variability in the polyphenol content of cashew apples, ranging from 22 to $295 \mathrm{mg} \mathrm{GAE} \times 100 \mathrm{~g}^{-1}$. This inconsistency can be explained by differences in soil, climate, growing season, postharvest storage and extraction methods(MELO et al., 2006; BARRETO et al., 2007; RUFINO et al., 2010). Plants may also activate polyphenol synthesis in response to stress, such as injury, pathogens or low nutrients (DIXON; PAIVA, 1995). 
Table 2 - Bioactive compounds and antioxidant capacity of cashew apples of early dwarf cashew clones at different ripening stages*.

\begin{tabular}{|c|c|c|c|c|c|c|c|c|c|}
\hline \multirow{2}{*}{ Variables } & \multirow{2}{*}{ lones } & \multicolumn{7}{|c|}{ Ripening Stages $^{1}$} & \multirow{2}{*}{$C V^{* *}$} \\
\hline & & 1 & 2 & 3 & 4 & 5 & 6 & 7 & \\
\hline \multirow{4}{*}{$\begin{array}{c}\text { Total } \\
\text { Vitamin C } \\
\left(\mathrm{mg} .100 \mathrm{~g}^{-1}\right)\end{array}$} & ССР 09 & $79.00 \mathrm{~dB}$ & $108.92 \mathrm{cB}$ & $128.22 \mathrm{bC}$ & $152.29 \mathrm{bB}$ & $210.41 \mathrm{aC}$ & $214.47 \mathrm{aB}$ & $226.11 \mathrm{aB}$ & 34.44 \\
\hline & CCP 76 & $73.06 \mathrm{cB}$ & $154.85 \mathrm{bA}$ & $164.36 \mathrm{bB}$ & $220.14 \mathrm{aA}$ & $229.14 \mathrm{aB}$ & $233.71 \mathrm{aB}$ & $248.00 \mathrm{aB}$ & 33.99 \\
\hline & BRS189 & $90.33 \mathrm{eA}$ & $101.18 \mathrm{eB}$ & $151.13 \mathrm{~dB}$ & $173.03 \mathrm{cB}$ & $202.97 \mathrm{bC}$ & $225.10 \mathrm{aB}$ & $236.03 \mathrm{aB}$ & 32.47 \\
\hline & BRS265 & $97.77 \mathrm{eA}$ & $173.41 \mathrm{dA}$ & $195.75 \mathrm{cA}$ & $209.64 \mathrm{cA}$ & $240.82 \mathrm{bA}$ & $271.54 \mathrm{aA}$ & $279.37 \mathrm{aA}$ & 28.49 \\
\hline \multirow{4}{*}{$\begin{array}{c}\text { Total } \\
\text { Carotenoids } \\
\left(\mathrm{mg} .100 \mathrm{~g}^{-1}\right)\end{array}$} & СР 09 & $0.09 \mathrm{eA}$ & $0.11 \mathrm{eA}$ & $0.22 \mathrm{dA}$ & $0.26 \mathrm{cA}$ & $0.29 \mathrm{cA}$ & 0.36 & 0.4 & 23.74 \\
\hline & CCP 76 & $0.19 \mathrm{eA}$ & $0.20 \mathrm{eA}$ & $0.23 \mathrm{dA}$ & $0.25 \mathrm{cA}$ & $0.27 \mathrm{cA}$ & $0.30 \mathrm{bA}$ & $0.41 \mathrm{aA}$ & 37.58 \\
\hline & BRS189 & $0.10 \mathrm{dA}$ & $0.17 \mathrm{cA}$ & $0.17 \mathrm{cA}$ & $0.20 \mathrm{cA}$ & $0.27 \mathrm{cA}$ & $0.31 \mathrm{aA}$ & $0.32 \mathrm{aA}$ & 35.98 \\
\hline & BRS265 & $0.19 \mathrm{dA}$ & 0.29 & $0.33 \mathrm{bA}$ & $0.34 \mathrm{bA}$ & 0.3 & 0.37 & $0.39 \mathrm{aA}$ & 21.71 \\
\hline \multirow{4}{*}{$\begin{array}{c}\text { Total } \\
\text { Anthocyanin } \\
\mathrm{s} \\
\left(\mathrm{mg} .100 \mathrm{~g}^{-1}\right)\end{array}$} & 99 & 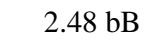 & 2 & & & & & & 45.79 \\
\hline & $\mathrm{CC}$ & & & & & & & & 27.65 \\
\hline & BRS189 & $5.80 \mathrm{eA}$ & $5.59 \mathrm{eA}$ & $8.45 \mathrm{dA}$ & $6.05 \mathrm{eA}$ & $9.74 \mathrm{cA}$ & $18.63 \mathrm{bA}$ & $21.16 \mathrm{aA}$ & 57.53 \\
\hline & BRS265 & $2.55 \mathrm{cB}$ & $2.83 \mathrm{cB}$ & $3.07 \mathrm{cB}$ & $4.19 \mathrm{bB}$ & $4.92 \mathrm{bB}$ & $4.92 \mathrm{bB}$ & $6.09 \mathrm{aB}$ & 30.28 \\
\hline \multirow{4}{*}{$\begin{array}{c}\text { Yellow } \\
\text { Flavonoids } \\
\left(\mathrm{mg} .100 \mathrm{~g}^{-1}\right)\end{array}$} & ССР 09 & $14.51 \mathrm{dC}$ & $23.13 \mathrm{cC}$ & $23.67 \mathrm{cC}$ & 23.8 & 29.28 & 30.3 & 33. & 22.70 \\
\hline & CCP 76 & $16.99 \mathrm{eC}$ & $18.57 \mathrm{eD}$ & $41.14 \mathrm{dA}$ & $44.47 \mathrm{cA}$ & $49.39 \mathrm{bA}$ & $49.56 \mathrm{bA}$ & $56.32 \mathrm{aA}$ & 16.61 \\
\hline & BRS189 & $20.26 \mathrm{~dB}$ & $27.65 \mathrm{cB}$ & $36.07 \mathrm{bB}$ & $47.46 \mathrm{aA}$ & $48.16 \mathrm{aA}$ & $48.87 \mathrm{aA}$ & $50.75 \mathrm{aB}$ & 28.98 \\
\hline & BRS265 & $27.94 \mathrm{cA}$ & $33.83 \mathrm{bA}$ & $34.46 \mathrm{bB}$ & $35.60 \mathrm{bB}$ & $36.73 \mathrm{aB}$ & $36.95 \mathrm{aB}$ & $38.82 \mathrm{aC}$ & 10.25 \\
\hline \multirow{4}{*}{$\begin{array}{l}\text { Total } \\
\text { Polyphenols } \\
\left(\mathrm{mg} 100 \mathrm{~g}^{-1}\right)\end{array}$} & ССР 09 & $375.79 \mathrm{aA}$ & $290.82 \mathrm{bA}$ & $286.31 \mathrm{bA}$ & $236.68 \mathrm{cA}$ & $222.90 \mathrm{dA}$ & 75.67 & 70.9 & 48.31 \\
\hline & CCP 76 & $124.20 \mathrm{aC}$ & $95.54 \mathrm{bD}$ & $91.72 \mathrm{bC}$ & $91.60 \mathrm{bB}$ & $74.82 \mathrm{cB}$ & $74.32 \mathrm{cA}$ & $64.01 \mathrm{dA}$ & 21.63 \\
\hline & BRS189 & $144.57 \mathrm{aB}$ & $116.96 \mathrm{bC}$ & $112.64 \mathrm{bB}$ & $97.28 \mathrm{cB}$ & $74.19 \mathrm{~dB}$ & $62.69 \mathrm{eB}$ & $54.85 \mathrm{eB}$ & 32.74 \\
\hline & BRS265 & $144.96 \mathrm{bD}$ & $129.77 \mathrm{aB}$ & $83.73 \mathrm{cC}$ & $78.38 \mathrm{cC}$ & $63.99 \mathrm{dC}$ & $76.56 \mathrm{cA}$ & $69.51 \mathrm{dA}$ & 26.70 \\
\hline \multirow{4}{*}{$\begin{array}{c}\text { Total } \\
\text { Antioxidant } \\
\text { Capacity } \\
(\mu \mathrm{mol} \\
\left.\text { Trolox.g- }^{1}\right)\end{array}$} & ССР 09 & $309.97 \mathrm{aA}$ & $235.00 \mathrm{bA}$ & $152.88 \mathrm{cA}$ & $101.31 \mathrm{dA}$ & $75.32 \mathrm{eA}$ & $26.49 \mathrm{gD}$ & $30.96 \mathrm{fD}$ & 75.68 \\
\hline & CCP 76 & $62.68 \mathrm{aB}$ & $62.75 \mathrm{aB}$ & $62.64 \mathrm{aB}$ & $57.80 \mathrm{bB}$ & $48.78 \mathrm{cB}$ & $45.70 \mathrm{cA}$ & $41.45 \mathrm{dA}$ & 16.01 \\
\hline & BRS189 & $31.88 \mathrm{cC}$ & $31.72 \mathrm{cD}$ & $41.17 \mathrm{aC}$ & $40.33 \mathrm{aD}$ & $36.81 \mathrm{bD}$ & $36.73 \mathrm{bB}$ & $36.62 \mathrm{bB}$ & 10.29 \\
\hline & BRS265 & $34.75 \mathrm{bC}$ & $43.74 \mathrm{aC}$ & $34.95 \mathrm{bD}$ & $45.78 \mathrm{aC}$ & $43.37 \mathrm{aC}$ & $29.95 \mathrm{cC}$ & $36.60 \mathrm{bB}$ & 15.73 \\
\hline
\end{tabular}

${ }^{1}$ Within clones, values with the same capital letters at the same stage are not significantly different at $\rho>0.05$ according the ScottKnott test. Between the stages of each clone, values with same small letters are not significantly different at $\rho>0.05$ according to the Scott-Knott test. $* \mathrm{n}=3$ (triplicate); $*$ Coefficient of variation.

Due to the complexity of the composition of foods, their antioxidant power depends on the synergistic effects and redox interaction between the different nutrient and "non nutrient" molecules, which together contribute to the possible health benefits. Therefore, attention has been given to the antioxidant activity of fruits, a parameter that allows a real evalution of the nutritional value of foods (LENUCCI et al., 2006; PELLEGRINI et al., 2007).

Regarding the antioxidant capacity, the four cashew apples clones evaluated showed completely different behaviors. Clone CCP 09 had the highest values during ripening until stage 5 and then the lowest when ripe (30.9 $\mu \mathrm{mol}$ Trolox $\left.\mathrm{x} \mathrm{g}^{-1}\right)$. This result indicates that polyphenols are the main contributor to the antioxidant capacity of this cashew clone, a notion also suggested by Melo et al. (2006). CCP 76 cashew apples showed a slight decrease during ripening. Meanwhile, the cashew apples from red BRS 189 and BRS 265 clones showed small increases in antioxidant capacity during ripening, with no significant differences between clones when ripe. Rufino et al. (2010) evaluated 18 native Brazilian fruit species for their antioxidant capacities and found, among the fruits analyzed, that cashew apples contain intermediate antioxidants levels and that antioxidant potential depends on the content of vitamins, carotenoids, flavonoids and other phenols.

Table 3 shows the correlation coefficient between vitamin $\mathrm{C}$, carotenoid, anthocyanin, yellow flavonoid and 
polyphenols content as well as the antioxidant capacity determined by ABTS assay of cashew apples from different cashew clones. A positive and significant correlation was found only for total polyphenols $(\mathrm{r}=$ $0.90 ; p<0.01$ ), confirming the results found for polyphenols and antioxidant capacity in Table 2, indicating that the more polyphenols present in the sample the greater the antioxidant capacity. All other evaluated parameters correlated negatively with antioxidant capacity, e.g. increased with the ripening of cashew apples during development and ripening, indicating that the higher content of vitamin $\mathrm{C}$, total anthocyanins, total carotenoids and yellow flavonoids decreased the antioxidant capacity of cashews apples. This differential presence/absence of correlation between antioxidant capacity values obtained with different classes of antioxidants compounds, could be due to a higher sensibility of the TEAC assays for such classes of compounds. Moreover, the test reaction used for antioxidant activity measurement might be differentially influenced by other compounds involved in complex antioxidant system such as glutathione and other enzymatic components (JIMÉNEZ et al., 2002).

Table 3 - Pearson's correlation (r) between bioactive compounds and capacity antioxidant of cashew apples of early cashew clones at ripening stages.

\begin{tabular}{lc}
\hline \multicolumn{1}{c}{ Variables } & Correlation \\
\hline Vitamin C & $-0.47 * *$ \\
Total carotenoids & $-0.53 * *$ \\
Total anthocyanins & $-0.27 *$ \\
Yellow flavonoids & $-0.49 * *$ \\
Total polyphenols & $0.90 * *$ \\
\hline
\end{tabular}

$* *$ Significant at $\rho<0.01$.

$*$ Significant at $\rho<0.05$.

Many other studies correlate the antioxidant activity with phenolic content (HEINONEN et al., 1998; IMEH; KHOKHAR, 2002; PINELO et al., 2004). Gardner et al. (2000) found that phenolics compounds contribute largely to the antioxidant capacity of non-citrus juices, while the carotenoids compounds showed negative correlations. Other authors (KALT et al., 1999) reported a negative influence of vitamin $\mathrm{C}$, showing ascorbate content and antioxidant capacity to be negatively correlated $(r=-0.80)$ for strawberries, raspberries and high-and low-bush blueberries.

\section{CONCLUSION}

In conclusion, the antioxidant activity of the cashew apples (Anacardium occidentale L.) is mainly attributed to polyphenol contents, and, therefore, they may be considered a relevant source of antioxidant compounds necessary for human health. BRS 265 and CCP 09 clones had the highest vitamin $\mathrm{C}$ and polyphenols contents, respectively. Cashew apples are consumed fresh, which confers direct benefits for human health. They also possess great potential for the development of new products with functional properties and, therefore, may be evaluated for the antioxidant supplements industry or studied by the food industry for the development of diverse products.

\section{ACKNOWLEDGEMENTS}

The authors would like to thank FUNCAP, CNPq, EMBRAPA, UFC and INFT.

\section{REFERENCES}

ALVES, R. E. et al. Antioxidant activity measurement in tropical fruits: A case study with acerola. Acta

Horticulturae, Leuven, v. 773, p.299-305, 2008.

BARRETO, G. P. M. et al. Bioactive compounds and free radical scavenger activity in ingredients prepared from the waste of the cashew-apple nut industry. Alimentos e Nutrição, Campinas, v. 18, n.2, p.207-213, 2007.

CHEMPAKAM, B. Distribution of ascorbic acid and ascorbic acid oxidase activity in developing cashew apple (Anarcadium occidentale, L.). Journal of Horticultural Science, Ashford, v. 58, n.3, p. 447-448, 1983.

CLIFFORD, M.N., 1995. Understanding the biological effects of dietary complex phenols and tannins and their implications for the consumer's health and well being.

Report of the European project FAIR-CT95-0653.

European Community Programme for Research,

Technological Development and Demonstration in the ûeld of Agriculture and Fisheries. 1995.

CONTRERAS-CALDERÓN, J. et al. Antioxidant capacity, phenolics contente and vitamin $\mathrm{C}$ in pulp, peel and seed from 24 exotic fruits from Colombia. Food Research International, v. 44, p.2047-2053, 2011.

DIXON, R. A.; PAIVA, N. L. Stress-induced phenylpropanoid metabolism. The Plant Cell, Rockville, v. 7, p.1085-1097, 1995. 
ESPIN, J. C. et al. Anthocyanin-based natural colorants: A new source of antiradical activity for foodstuff. Journal of Agricultural and Food Chemistry, Washington, v. 48, n.5, p.1588-1592, 2000.

FILGUEIRAS, H. A. C. et al. Cashew apple for fresh consumption: research and post-harvest handling technology in Brazil. Acta Horticulturae, Leuven, v. 485, p.155-160, 1999.

FRANCIS, F. J. Analysis of anthocyanins. In:MARKAKIS, P. (Ed.), Anthocyanins as food colors. New York: Academic Press, p. 181-207. 1982.

GARDNER, P. T. et al. The relative contributions of vitamin $\mathrm{C}$, carotenoids of phenolic to the antioxidant potential of fruit juices. Food Chemistry, Barking, v. 68, p.471-474, 2000 .

HEINONEN, I. M., LEHTONEN, P. J.; HOPIA, A. I. Antioxidant activity of berry and fruit wines and liquors. Journal of Agricultural Food Chemistry, Washington, v. 46, p.25-31, 1998.

HIGBY, W. K. A simplified method for determination of some the carotenoids distribution in natural and carotene-fortified orange juice. Journal of Food Science, Chicago, v. 27, n.1, p.42-49, 1962.

ILAHY, R. et al. Antioxidant activity and bioactive compounds changes during fruit ripening of highlycopene tomato cultivars. Journal of Food and Composition and Analysis, Oxford, v. 24, p.588-595, 2011.

IMEH, U.; KHOKHAR, S. Distribution of conjugated and free phenols in fruits: Antioxidant activity and cultivar variations. Journal of Agricultural Food Chemistry, Washington, v. 50, p.6301-6306, 2002.

JIMÉNEZ, A. et al. Changes in oxidative processes and components of the antioxidant system during tomato fruit ripening. Planta, Heidelberg, p. 214, 751-758, 2002.

KALT, W. et al. Antioxidant capacity, vitamin C, phenolics, and anthocyanins after fresh storage of small fruits. Journal of Agricultural Food Chemistry, Washington, v. 47, n.11, p.4638-4644, 1999.

LARRARRAURI, J. A., RUPÉREZ, P., SAURACALIXTO, F. Effect of drying temperature on the stability of polyphenols and antioxidant activity of red grape pomace peels. Journal of Agricultural and Food Chemistry, Washington, v. 45, n.4, p.1390-1393, 1997.

LENUCCI, M. S. et al. Antioxidant composition in cherry and high-pigment tomato cultivars. Journal of Agricultural and Food Chemistry, Washington, v. 54, p.2606-2613, 2006.

MELO, E. de A., LIMA, V. L. A. G. de, MACIEL, M. I. S. Polyphenol, ascorbic acid and total carotenoid contents in common fruits and vegetables. Brazilian Journal of Food Technology, Campinas, v. 19, p. 89-94, 2006.

MEZADERI, T. et al. Antioxidant compounds and antioxidant a ctivity in acerola (Malpighia emarginata DC) fruits and derivates. Journal of Food and Composition and Analyses, Oxford, v.21, p.282-290, 2008.

MICHODJEHOUN-MESTRE, L. et al. Monomeric phenols of cashew apple (Anacardium occidentale L.). Food Chemistry, Barking, v.112, n.4, p.851-857, 2009.

OBANDA, M., OWUOR, P. O. Flavonol composition and caffeine content of green leaf as quality potential indicators of Kenyan black teas. Journal of the Science of Food and Agriculture, London, v. 74, n.2, 209-215, 1997.

PARK, Y. S. et al. Comparison of the contents of bioactive compounds and the level of antioxidant activity in different kiwifruit cultivars. Journal of Food and Composition and Analysis, Oxford, v.24, p. 963-970, 2011.

PELLEGRINI, N. et al. Evaluation of antioxidant capacity of some fruit and vegetable foods: efficiency of extraction of a sequence of solventes. Journal of the Science of Food and Agriculture, London, v.87, p.103111, 2007.

PETINARI, R. A., TARSITANO, M. A. A. Cashew (Anacardium occidentale L.) commercialization in northwest of São Paulo state. Revista Brasileira de Fruticultura, Jaboticabal, v.24, p.700-702, 2002.

PINELO, L. et al. Solvent effect on quercetin antioxidant capacity. Food Chemistry, Barking, v.88, n.2, p.201-207, 2004. 
RE, R. et al. Antioxidant activity applying an improved ABTS radical cation decolorization assay. Free Radical Biology \& Medicine, Los Angeles, v.26, p. 1231-1237, 1999.

RUFINO, M. S. M. et al. Bioactive compounds and antioxidant capacities of 18 non-traditional tropical fruits from Brazil. Food Chemistry, Barking, v.121, n.4, p.996$1002,2010$.

SAURA-CALIXTO, F., GOÑI, I. Antioxidant capacity of the Spanish Mediterranean diet. Food Chemistry, Barking, v.94, p.442-447, 2006.

SILVA, P. T. et al. Estabilidades química, físico-química e microbiológica do suco de laranja cv. pera submetido a diferentes condições de estocagem. Boletim do Centro de Pesquisa e Processamento de Alimentos, Curitiba, v.25, p.235-246, 2007.
STROHECKER, R., HENNING, H. M. Análisis de vitaminas: Métodos comprobados. Madrid: $\mathrm{Paz}$ Montalvo, 1967, 428p.

SUJA, K. P., JAYALEKSHMY, A., ARUMUGHAN, C. Free radical scavenging behavior of antioxidant compounds of sesame (Sesamum indicum L.) in DPPH system. Journal of Agricultural and Food Chemistry, Washington, v.52, p.912-915, 2004.

THILI, I. et al. Bioactive componds and antioxidant activities during fruit ripening of watermelon cultivars. Journal of Food and Composition and Analysis, Oxford, v.24, p.923-928, 2011.

WORLD HEALTH ORGANIZATION - WHO. Diet, nutrition and the prevention of chronic diseases: report of a joint WHO/FAO expert consultation. WHO Reports, 2003. 